\title{
Intraoral epithelioid hemangioendothelioma: A case report and review of the literature
}

\author{
Manuel-Antonio Gordón-Núñez ${ }^{1}$, Leonardo-Miguel-Madeira Silva ${ }^{2}$, Maria-Fernanda-Fernandes Lopes ${ }^{2}$, \\ Sebastião-Fernandes de Oliveira-Neto ${ }^{3}$, Alexandre-Pinto Maia ${ }^{4}$, Hébel-Cavalcanti Galvão ${ }^{5}$
}

\author{
${ }^{1}$ Postdoctoral Fellow IFARHU/SENACYT 2005-2010 Postdoctoral Program-Panamá / Post Graduation Program in Oral Patho- \\ logy, Rio Grande do Norte Federal University-UFRN, Natal/RN, Brazil \\ ${ }^{2}$ Research Base in Oral Pathology, Dentistry Department, Rio Grande do Norte Federal University - UFRN, Natal/RN, Brazil \\ ${ }^{3}$ Surgery Discipline I, Dentistry Department, Rio Grande do Norte Federal University - UFRN, Natal/RN, Brazil \\ ${ }^{4}$ Postgraduation Program in Oral Pathology, Dentistry Department, Rio Grande do Norte Federal University - UFRN, Natal/ \\ RN, Brazil \\ ${ }^{5}$ Oral Pathology Discipline, Dentistry Department, Rio Grande do Norte Federal University - UFRN, Natal/RN, Brazil
}

Correspondence:

Av. Senador Salgado Filho, 1787

Lagoa Nova. Natal-RN,

CEP: 59056-000

gordonnunez28@yahoo.com

Received: 03/02/2009

Accepted: $12 / 09 / 2009$

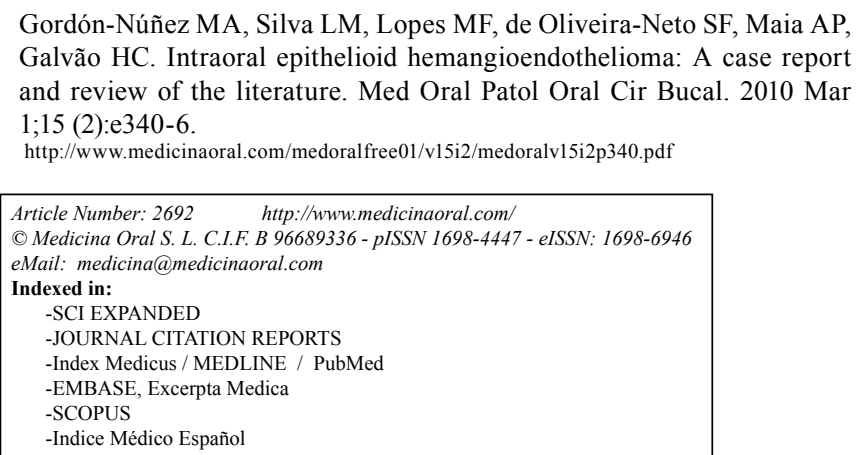

Gordón-Núñez MA, Silva LM, Lopes MF, de Oliveira-Neto SF, Maia AP, Galvão HC. Intraoral epithelioid hemangioendothelioma: A case report and review of the literature. Med Oral Patol Oral Cir Bucal. 2010 Mar 1;15 (2):e340-6.

http://www.medicinaoral.com/medoralfree01/v15i2/medoralv15i2p340.pdf

Article Number: $2692 \quad$ http://www.medicinaoral.com

(C) Medicina Oral S. L. C.I.F. B 96689336 - pISSN 1698-4447 - eISSN: 1698-6946

eMail: medicina@medicinaoral.com

Indexed in:

-SCI EXPANDED

-JOURNAL CITATION REPORTS

-Index Medicus / MEDLINE / PubMed

-EMBASE, Excerpta Medica

-SCOPUS

-Indice Médico Español

\begin{abstract}
The epithelioid hemangioendothelioma $(\mathrm{EH})$ is an uncommon angiocentric neoplasm of borderline or intermediate malignant potential, between the hemangioma and conventional angiosarcoma. It is characterized by the proliferation of endothelial cells with epithelioid or histiocitóide morphology with vacuolated cytoplasm and occasional eosinophilic spindle cells. Shows potential for local recurrence as well as the ability to metastasize. Rarely affects the oral cavity, it have been described from 1975 until 2008 only 27 oral cases. Morphologically the EHs may be confused with other lesions, from a hemangioma to a squamous cell carcinoma, and thus immunohistochemical analysis is required. This paper reports the clinical and immunohistochemical characteristics of a case of EH in the gingiva of the tooth 35 of a 17 years-old-white-female. We present a review of the clinicopathological and immunohistochemical characteristics of the intraoral epithelioid hemangioendothelioma cases previously reported.
\end{abstract}

Key words: Epithelioid hemangioendothelioma, intraoral, vascular neoplasm.

\section{Introduction}

The term hemangioendothelioma was introduced by Borrmann who first proposed the concept of vascular neoplasms with intermediate or low malignant potential (1). Three histological types of hemangioendothelioma are known: kaposiform, hobnail (or Dabska-retiform), and epithelioid (2).

The epithelioid hemangioendothelioma (EH) type was first described by Weiss and Enzinger in 1982 as a angiocentric neoplasm characterized by neoplastic proliferation of epithelioid or histiocytoid endothelial cells, showing eosinophilic vacuolated cytoplasm, and occasionally, fusiform cells. The cell proliferation can be arranged as short anastomosing cords, solid lobules or lining distinct primitive-appearing vascular channels, with erythrocytes occasionally seen in the lumina. 
Frequently, the tumor cells are arranged within a fibromyxoid stroma (3).

This tumor primarily committed to the soft tissues of the extremities (4), cases have been reported in lung, liver, bones, skin and the head and neck region, including the oral cavity (4-6). The EH is rare in the head and neck region and even more rare in the oral cavity, with 27 cases described from 1975 to 2008 .

The EHs are usually treated with surgical removal of primary tumors, research the possibility of metastatic lesions and clinical follow-up of the patient due to risk of recurrence (7).

It reported a case of intraoral epithelioid hemangioendothelioma and a literature review is presented focused on clinical-pathological features and immunohistochemistry of the intraoral cases reported in the MEDLINE data base.

\section{Case Report}

A 17-year-old white woman, with 1 year history of a lesion in the gingiva after extraction of the 35 tooth, with pink color, exophytic, firm, painless, rapid growth, pediculated, without radiographic appearance and clinical diagnosis of pyogenic granuloma. A incisional biopsy was performed and microscopic examination showed a fragment of a vascular neoplasia characterized by the proliferation of ovoid and fusiform endothelial cells, with a discrete cellular and nuclear pleomorphism, arranged in nests and cords. Some cells had an abundant eosinophilic cytoplasm and a hyperchromatic nuclei; others, sometimes, showed occasional intracytoplasmic vacuoles (Fig. 1A).

Cell proliferation can be seen scattered in the scanty stroma of lax connective tissue or limiting rudimentary vascular spaces, with erythrocytes occasionally seen in the lumina (Fig. 1B), in addition to areas with mineralized amorphous material between cell proliferation (Fig. 1C). (Table 1) shows the specifications of the antibodies used. Immunopositivity was observed for CD31 (Fig. 1D), CD34 (Fig. 2A), factor VIII-RAg (Fig. 2B), vimentin (Fig. 2C) and focal staining to SMA, mainly in myopericitics cells surrounding the neoplastic cells, showing endothelial differentiation (Fig. 2D). Negativity was observed for EMA, S-100, cytokeratins (AE-1 and AE-3) and CD68.

Based on morphological and immunohistochemical findings, the lesion was diagnosed as epithelioid hemangioendothelioma. The patient is in regular followup and 14 months after the surgery, no abnormalities were found on physical examination.
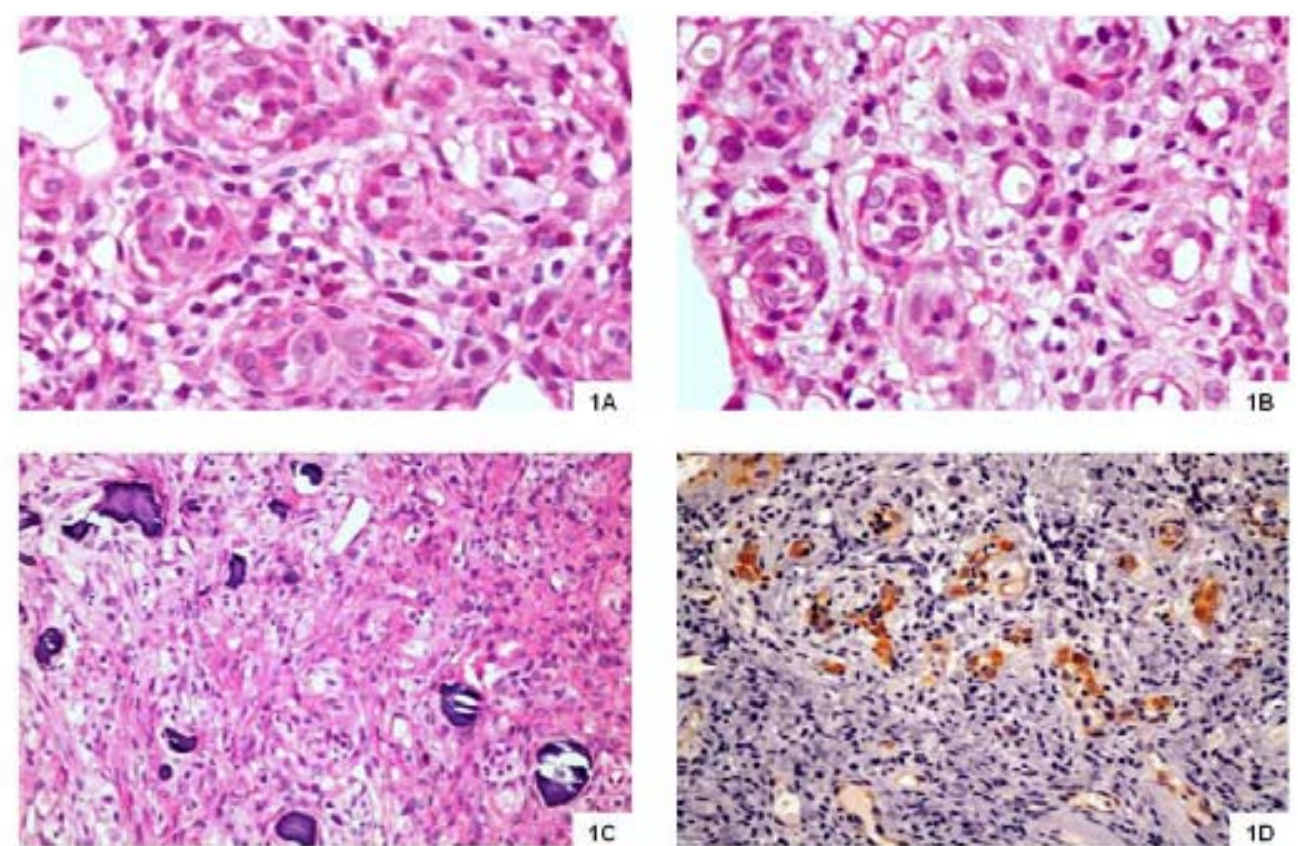

Fig. 1. A. Intense proliferation of neoplastic cells with abundant eosinophilic cytoplasm and hyperchromatic nuclei, and cells with occasional intracytoplasmic vacuoles, H/E - 200x; 1B. Cellular proliferation lining vascular structures, some of which containing erythrocytes and some cells with aspect of "signet ring-like", H/E - 200x; 1C. Amorphous mineralized material suggestive of metaplastic bone formation scattered between the proliferation of spindle and epithelioid neoplastic cells; 1D. Immunopositivity for CD31 in epithelioid-like neoplastic endotelial cells, SABC - 100x. 
Table 1. Specifications of the antibodies used.

\begin{tabular}{|l|l|l|c|c|c|}
\hline ANTIBODY & CLONE & \multicolumn{1}{|c|}{ SOURCE } & DILUITION & ANTIGENIC RETRIEVAL & $\begin{array}{c}\text { INCUBATION } \\
\text { TIME }\end{array}$ \\
\hline CD31 & JC/70A & Dako, CA, USA & $1: 40$ & Citrato pH 6.0, Pascal & Overnight \\
\hline CD34 & $\begin{array}{l}\text { QBEnd- } \\
10\end{array}$ & Dako, CA, USA & 1.50 & Tris EDTA pH 9, Pascal & Overnight \\
\hline Factor VIII & F8/86 & Dako, CA, USA & $1: 400$ & Citrato pH 6.0, Pascal & 30 min \\
\hline Vimentin & V9 & Dako, CA, USA & $1: 50$ & Citrato pH 6.0, Pascal & 30 min \\
\hline SMA & $\alpha s m-1$ & Novocastra, London, UK & $1: 40$ & Citrato pH 6.0, Pascal & 60 min \\
\hline EMA & E29 & Dako, CA, USA & $1: 40$ & Sin tratamiento & 60 min \\
\hline S-100 & S-100 & Dako, CA, USA & $1: 100$ & Citrato $p H$ 6.0, Pascal & 30 min \\
\hline $\begin{array}{l}\text { Cytokeratins } \\
\text { (AE-1/EA-3) }\end{array}$ & $\begin{array}{l}\text { A E - } 1, \\
\text { EA-3 }\end{array}$ & Dako, CA, USA & $1: 500$ & Citrato $p H$ 6.0, Pascal & 120 min \\
\hline CD68 & KP1 & Santa Cruz, CA, USA & $1: 50$ & Citrato $p H$ 6.0, Pascal & Overnight \\
\hline
\end{tabular}
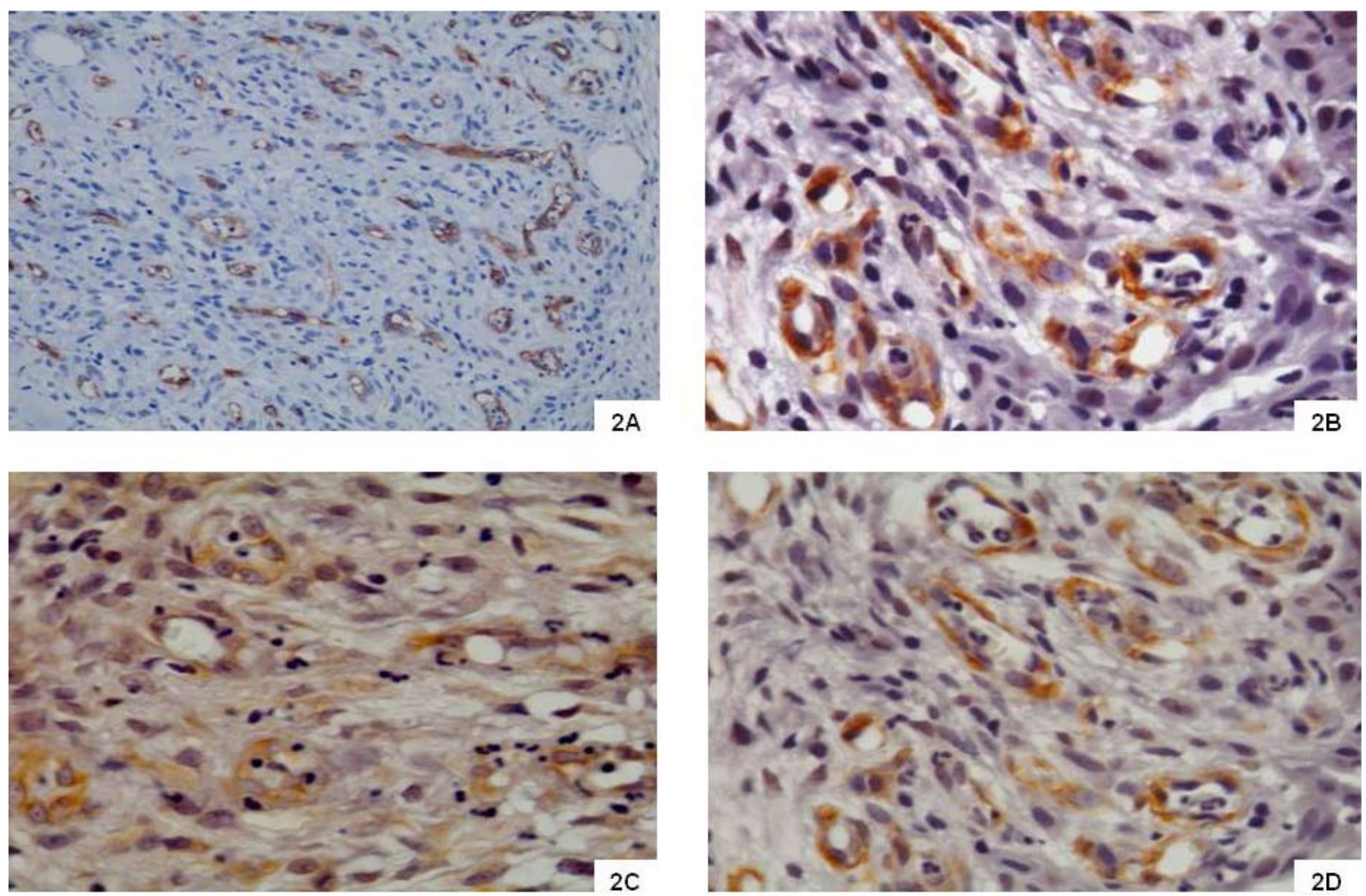

Fig. 2. A. Immunopositivity for CD34 in epiteliod-like neoplastic endotelial cells, SABC-100x; 2B. Cytoplasmic immunostaining for FVIIIRAg, SABC-400x; 2C. Immunostaining for Vimentin, SABC-400x; 2D. Immunostaining for SMA, SABC-400x. 


\section{Discussion}

The analysis of cases of intraoral epithelioid hemangioma reported in the literature is a relatively difficult task, once the lesion from years ago has received various names, such as "hemangioendothelioma", "malignant hemangioendothelioma" and "histiocytoid hemangioma" (7-9), thus, the reference point selected for the literature review presented here is the work published in 1975 by Wesley et al. (8), entitled "Primary malignant hemangioendothelioma of the gingiva", until the most recent reported case by Mohtasham et al. (10).

(Table 2) shows the epidemiological data of the EHs reported in the literature in journals indexed in PubMed, including the case reported here. Most cases were clinically diagnosed as benign entities including pyogenic granuloma, fibroma, peripheral giant cell granuloma, peripheral ossifying fibroma, inflammatory fibrous hyperplasia and necrotizing ulcerative gingivitis (11). The case reported here is consistent with the literature, once the hypothesis of clinical diagnosis was pyogenic granuloma. The fact that the majority of EHs are clinically diagnosed as benign lesions has a great relevance, since it is a neoplasm with malignant biological behavior, intermediate between the hemangioma and conventional angiosarcoma, with reported cases displaying aggressive behavior and multiples recurrences $(10,12)$.

It was noted that only 2 cases (7.4\%) reported pain associated with the lesion, while the majority had no information about the symptoms, which leads us to infer that they were asymptomatic or that this was not just informed by authors (Table 2). The case reported here was asymptomatic.

The analysis of radiographic features showed that $25.9 \%$ of the lesions were associated with resorption or destruction of underlying bone (Table 2), highlighting the need for careful radiographic examination of the lesions to investigate possible alterations of the bone (11). It was not found any radiographic changes in the case reported here.

The malignant potential of the EHs is not well established, however, based on cases reported in the literature, these neoplasms exhibit a biological behavior intermediate between hemangioma and angiosarcoma, as well as potential for recurrence and metastasis (3).

Predictions regarding the biological behavior of EH in the oral region are not entirely possible due to the rarity of the lesion, the lack of agreement relative to terminology and criteria for diagnosis of $\mathrm{EH}$ and because of differences in the biologic behavior of these tumors relative to both their anatomic sites and with regard to age of occurrence (6).

Furthermore, EH doesn't shows, histopathologically, consistent criteria for predicting their biologic behavior, however, it is reported that the presence of a increased number of mitotic figures and cellular atypia, spindle tumor cells, metaplastic bone formation, in addition to areas of focal necrosis can be morphological signs of lesions with more aggressive phenotype and consequently more reserved prognosis, with recurrences and regional and/or distant metastasis $(1,6,11)$. The case reported here showed no relevant cellular atypia or mitotic activity, which leads us to suggest that probably could be a lesion with more indolent behavior.

The review of the literature showed that the most prevalent intraoral site for EH was the tongue (7-25.9\%), followed by the mandibular gingiva (6-22.2\%) and maxillary gingiva (5-18.5\%). The size of lesions ranged from $0.2 \mathrm{~cm}$ to $7.0 \mathrm{~cm}$, with a mean of $1.7 \mathrm{~cm}$. In the eight reported cases with recurrence (29.6\%) (Table 2), it was noted that, in some of them, were multiple recurrences and the recurrent lesions showed a more aggressive appearance of malignancy. These recurrences were more frequent in the maxillary gingiva and buccal mucosa, both with $25.9 \%$, followed by the lower lip, tongue, jaw and maxilla, with $12.9 \%$, respectively. There are no reports of recurrence in mandibular gingiva and this site is the same of the case here reported.

The case reported here agrees with the literature (3) regarding the histomorphological features. The lesion exhibit cells with prominent cytoplasmic vacuoles, which represent primitive-appearing vascular channels; it is reported that these vacuoles are negative for mucin and erythrocytes occasionally seen in the lumina. The EHs can exhibit mineralized material, reported by some authors as metaplastic bone formation, in addition to numerous osteoclast-like giant cells. It reported that the metaplastic bone formation with significant cellular atypia, mitotic activity greater than one per 10 highpower fields, an increased proportion of spindle tumor cells and focal necrosis represent histopathological factors associated with a more aggressive behavior of the lesion $(1,13,14)$.

Due to the predominant morphological characteristics, the EHs can be confused with other lesions including hemangioma to squamous cell carcinoma, therefore, emphasizes the importance of immunohistochemical analysis to establish the definitive diagnosis. In this context, the review of published cases verified that the majority of intraoral EHs lesions were immunoreactive for CD34, CD31, factor VIII-RAg and vimentin, these markers characterize the epithelioid endothelial origin of this entity (Table 3). It is reported that the immunoreactivity for factor VIII-RAg indicates the cytoplasmatic luminal features and the epithelial cellular neoplastic nature (11). Furthermore, we agree with the literature that due to the morphological appearance of epithelioid tumoral cells of the EHs an the fact that many lesions are reactive for cytokeratin (AE-1/AE-3), requires a lot of attention from the pathologist, to avoid the risk of misdiagnosed as squamous cell carcinoma (13). 
Table 2. Clinical and radiographic features of the intraoral EH cases reported in the literature.

\begin{tabular}{|c|c|c|c|c|c|c|}
\hline & AUTHOR (YEAR) & AGE & SEX & LOCALIZATION & $\begin{array}{c}\text { CLINICAL AND RADIOGRAPHIC } \\
\text { HISTORY }\end{array}$ & FOLLOW-UP \\
\hline 1 & Wesley et al (1975) & 18 & $\mathrm{~F}$ & Mandibular gingiva & $\begin{array}{l}\text { Reddish erosive lesion, (34 to } 36 \text { ), bone } \\
\text { resorption }\end{array}$ & 2 years SFL \\
\hline 2 & Ellis, Kratochvil (1986) & 13 & $\mathrm{~F}$ & Maxillary gingiva & Swelling, pink, tooth mobility, 4 years & 6 years SFL \\
\hline 3 & Ellis, Kratochvil (1986) & 4 & $\mathrm{~F}$ & Mandibular gingiva & Tooth mobility, bone resorption & NI \\
\hline 4 & Moran et al (1987) & 25 & $\mathrm{~F}$ & Palate & Swelling, $1.0 \mathrm{~cm}, 1$ year & 21 months SFL \\
\hline 5 & de Araujo et al (1987) & 4 & M & Mandibular gingiva & $\begin{array}{l}\text { Swelling, ulceration, tooth mobility, } 9 \\
\text { months }\end{array}$ & NI \\
\hline 6 & Marrogi et al (1991) & 45 & M & Maxillary gingiva & Erythematous lesion, $1.5 \mathrm{~cm}$ & 3,6 months Rec \\
\hline 7 & Marrogi et al (1991) & 36 & $\mathrm{~F}$ & Tongue & Painful nodules, $0.2 \mathrm{~cm}, 2$ months & 17 months SFL \\
\hline 8 & Flaitz et al (1995) & 7 & $\mathrm{~F}$ & Mandibular gingiva & $\begin{array}{l}\text { Reddish swelling, } 1.5 \mathrm{~cm} \text {, tooth mobility, } \\
\text { bone destruction }\end{array}$ & 52 months SFL \\
\hline 9 & Hamakawa et al (1999) & 76 & $\mathrm{~F}$ & $\begin{array}{l}\text { Mandibular anterior re- } \\
\text { gion }\end{array}$ & $\begin{array}{l}\text { Submucous swelling, soft, } 4.5 \mathrm{~cm} \text {, bone } \\
\text { destruction }\end{array}$ & 6 years SFL \\
\hline 10 & Orsini et al (2001) & 18 & $\mathrm{~F}$ & Buccal mucosa & $\begin{array}{l}\text { Asymptomatic swelling, } 1.5 \mathrm{~cm}, 7 \text { mon- } \\
\text { ths }\end{array}$ & 9 months Rec \\
\hline 11 & Ramer et al (2001) & 32 & M & Maxilla & Swelling, $3.5 \mathrm{~cm}$ & 6 months Rec \\
\hline 12 & $\begin{array}{l}\text { Molina Palma et al } \\
(2002)\end{array}$ & 65 & $\mathrm{~F}$ & Tongue & Swelling , $0.5 \mathrm{~cm}, 2$ months & 21 months SFL \\
\hline 13 & Machalka et al (2003) & 65 & M & Jawa & $\begin{array}{l}\text { Swelling at the anterior region of jaw, } \\
\text { tooth mobility }\end{array}$ & 4.8 years Rec \\
\hline 14 & Anderson et al (2003) & 18 & $\mathrm{~F}$ & Lower lip & Asymptomatic swelling, 6 months & 4 months Rec \\
\hline 15 & Chi et al (2005) & 28 & $\mathrm{~F}$ & Maxillary gingiva & Purple swelling, $0.6 \mathrm{~cm}$ & 8 months SFL \\
\hline 16 & Chi et al (2005) & 23 & $\mathrm{~F}$ & Jaw & $2.0 \mathrm{~cm}$, bone destruction & NI \\
\hline 17 & Sun et al (2007) & 12 & M & Maxillary gingiva & $\begin{array}{l}\text { Ulcerated swelling, } 3.0 \mathrm{~cm}, 3 \text { months, } \\
\text { bone destruction, tooth mobility }\end{array}$ & 6 months SFL \\
\hline 18 & Sun et al (2007) & 53 & M & Buccal mucosa & Swelling, $1.5,6$ months & 9 months Rec \\
\hline 19 & Sun et al (2007) & 17 & M & Tongue & Soft swelling, $0.5 \mathrm{~cm}, 2$ months & 18 months SFL \\
\hline 20 & Sun et al (2007) & 52 & $\mathrm{~F}$ & Upper lip & Purple swelling, $2.0 \mathrm{~cm}, 1$ year & 3 years SFL \\
\hline 21 & Sun et al (2007) & 21 & M & Tongue & Reddish swelling, $0.5 \mathrm{~cm}, 2$ months & 2 years SFL \\
\hline 22 & Sun et al (2007) & 34 & M & Tongue & Swelling, $1.0 \mathrm{~cm}, 4$ months & 6 years SFL \\
\hline 23 & Sun et al (2007) & 11 & M & Mandibular gingiva & $\begin{array}{l}\text { Painful swelling, } 2.0 \mathrm{~cm}, 1 \text { month, bone } \\
\text { destruction, tooth mobility }\end{array}$ & 8 years SFL \\
\hline 24 & Sun et al (2007) & 46 & $\mathrm{M}$ & Tongue & Reddish swelling, $1.2 \mathrm{~cm}$ & 4 months Rec \\
\hline 25 & Sun et al (2007) & 6 & $\mathrm{M}$ & Floor of mouth and tongue & Reddish swelling, $7.0 \mathrm{~cm}, 6$ months & 2 years SL \\
\hline 26 & $\begin{array}{l}\text { Mohtasham et al } \\
(2008)\end{array}$ & 9 & M & Maxillary gingiva & $\begin{array}{l}\text { Ulcerated reddish swelling, asymptom- } \\
\text { atic, } 1.0 \mathrm{~cm}, 6 \text { months }\end{array}$ & 1 year, Rec \\
\hline 27 & $\begin{array}{l}\text { Gordón-Núñez et al } \\
\text { (2008) }\end{array}$ & 17 & $\mathrm{~F}$ & Mandibular gingiva & Swelling, pink, $2,0 \mathrm{~cm}, 1$ year & 9 months, SFL \\
\hline
\end{tabular}

M: male; F: female; NI: no information; SFL: survival free of lesion; SL: survival with lesion; Rec: recurrence.

A variable immunohistochemical expression to SMA for intraoral EHs has been observed previously $(12,15,16)$ (Table 3). In the case reported here the immunoreactivity for this marker was focally, as evidenced at times immunoreactivity in myopericitics cells surrounding the neoplastic cells, showing the endothelial differentiation of these. The nuclear transcription factor Fli-1, a specific marker for Ewing's sarcoma and primitive neuroectodermal tumor, has been sensitive to vascular lesions, including EH (15).

Considering the intermediate malignant potential of the $\mathrm{EH}$, wide local excision was the mode of choice in most cases reported in the literature $(6,11,15,17)$, it was observed that conservative procedures such as curettage may favor the recurrence of the lesions (18). Under this, after established a diagnosis of EH the correct treatment should al- 
Table 3. Immunohistochemical analisis of the intraoral EH cases reported in the literature.

\begin{tabular}{|c|c|c|c|c|c|c|c|c|c|c|c|c|}
\hline & $\begin{array}{c}\text { AUTHOR } \\
\text { (year) }\end{array}$ & CD34 & CD31 & CD68 & $\begin{array}{c}\text { Factor } \\
\text { VIII-RAg }\end{array}$ & VIMENTIN & SMA & S-100 & EMA & $\begin{array}{l}\text { AE-1/ } \\
\text { AE-3 }\end{array}$ & Fli-1 & VEGF \\
\hline 1 & $\begin{array}{l}\text { Ellis, Kratochvil } \\
\text { (1986) }\end{array}$ & & & & + & & & & & & & \\
\hline 2 & $\begin{array}{l}\text { Ellis, Kratochvil } \\
\text { (1986) }\end{array}$ & & & & + & & & & & & & \\
\hline 3 & $\begin{array}{l}\text { Moran et al } \\
\text { (1987) }\end{array}$ & & & & + & & & & & & & \\
\hline 4 & $\begin{array}{l}\text { Flaitz et al } \\
(1995)\end{array}$ & & & & + & & & & & & & \\
\hline 5 & $\begin{array}{l}\text { Hamakawa et al } \\
\text { (1999) }\end{array}$ & + & & & + & + & & - & - & - & & \\
\hline 6 & $\begin{array}{l}\text { Orsini et al } \\
(2001)\end{array}$ & & & & + & & & & & & & \\
\hline 7 & $\begin{array}{l}\text { Ramer et al } \\
(2001)\end{array}$ & + & & & + & & & & & & & \\
\hline 8 & $\begin{array}{l}\text { Molina Palma et } \\
\text { al (2002) }\end{array}$ & & + & & + & & & & & & & \\
\hline 9 & $\begin{array}{l}\text { Machalka et al } \\
(2003)\end{array}$ & + & + & - & + & + & + & - & & - & & \\
\hline 10 & Chi et al (2005) & - & + & - & & & - & - & - & - & + & \\
\hline 11 & Chi et al (2005) & + & + & - & & & + & - & - & - & + & \\
\hline 12 & Sun et al (2007) & + & & & + & + & + & - & - & + & & \\
\hline 13 & Sun et al (2007) & + & & & + & + & + & - & - & + & & \\
\hline 14 & Sun et al (2007) & + & & & + & + & + & - & - & + & & \\
\hline 15 & Sun et al (2007) & + & & & + & + & + & - & - & - & & \\
\hline 16 & Sun et al (2007) & + & & & + & + & + & - & - & - & & \\
\hline 17 & Sun et al (2007) & + & & & + & + & + & - & - & - & & \\
\hline 18 & Sun et al (2007) & + & & & + & + & + & - & - & - & & \\
\hline 19 & Sun et al (2007) & + & & & + & + & + & - & - & - & & \\
\hline 20 & Sun et al (2007) & + & & & & & + & - & - & - & & \\
\hline 21 & $\begin{array}{l}\text { Mohtasham et al } \\
\text { (2008) }\end{array}$ & + & + & & & & & & & & & \\
\hline 22 & $\begin{array}{l}\text { Gordón-Núñez } \\
\text { et al (2008) }\end{array}$ & + & + & - & + & + & + & - & - & - & & \\
\hline
\end{tabular}

(+) Immunopositivity, (-) Immunonegativity.

ways be the total surgical removal of the lesion and followup, to avoid the risk of permanence of neoplastic material and consequently recurrence. Therapeutic modalities as chemo and / or radiotherapy have been suggested for the treatment of $\mathrm{EH}$, but without satisfactory results.

Among the 27 cases of intraoral EHs reported in the literature, including the case of this paper was observed that 23 cases $(85.2 \%)$ had clinical follow-up information. Most of the patients (15-55.6\%) survive free of evidence of lesion. On the other hand, 8 lesions (29.6\%) recurred locally and fortunately was not registered a local or distant metastasis, nor death associated with lesions (Table 2). These data reinforce the less aggressive nature of the intraoral EHs when compared with those who commit other regions of the body.
The differential diagnosis of EH with another entities that occurs at the oral cavity may be assisted by certain clinical, histopathological, biochemical and/ or immunohistochemistry. In this context, relates that epithelioid hemangioma, for example, is an lesion that usually exhibits cells with voluminous and eosinophilic cytoplasm, may be associated with lymphadenopathy and eosinophilia with elevated $\mathrm{IgE}$ and unlike the HE, epithelioid hemangiomas are located superficially, multilobular, not exhibit endothelial cells, cells with intracytoplasmic vacuoles, atypia, mitosis and necrosis (11). The association of epithelioid hemangioma with lymphadenopathy, peripheral eosinophilia and increased $\mathrm{IgE}$ are factors that help in the differential diagnosis (13). 
In relation to the pyogenic granuloma, the diagnosis can be assisted by the clinical appearance of the lobular lesion. Furthermore, the squamous cell carcinoma, unlike the EH, the factor VIII-RAg, Eulex and mucin are negative. The absence of epithelioid cells with intracytoplasmic vacuoles, presence of fibrossarcoma-like spindle cells assist to differentiate Kaposi sarcoma of the EH (1).

Based on the analysis of the literature and in the case reported here, we conclude that the EHs are angiosarcomas whose etiology remains unknown, exhibiting particular histopathological and immunohistochemical features, being required a careful evaluation and with various diagnostic techniques to recognize and treat properly this entity, mainly taking into account their relatively malignant biological behavior.

\section{References}

1. Marrogi AJ, Boyd D, El-Mofty S, Waldron C. Epithelioid hemangioendothelioma of the oral cavity: report of two cases and review of literature. J Oral Maxillofac Surg. 1991;49:633-8.

2. Nascimento AG, Keeney GL, Sciot R, Fletcher CD. Polymorphous hemangioendothelioma: a report of two cases, one affecting extranodal soft tissues, and review of the literature. Am J Surg Pathol. 1997;21:1083-9.

3. Weiss SW, Enzinger FM. Epithelioid hemangioendothelioma: a vascular tumor often mistaken for a carcinoma. Cancer. 1982;50:970-81. 4. Makhlouf HR, Ishak KG, Goodman ZD. Epithelioid hemangioendothelioma of the liver: a clinicopathologic study of 137 cases. Cancer. 1999;85:562-82.

5. Pigadas N, Mohamid W, McDermott P. Epithelioid hemangioendothelioma of the parotid salivary gland. Oral Surg Oral Med Oral Pathol Oral Radiol Endod. 2000;89:730-8.

6. Orsini G, Fioroni M, Rubini C, Piattelli A. Epithelioid hemangioendothelioma of the oral cavity: report of case. J Oral Maxillofac Surg. 2001;59:334-7.
7. Anderson PJ, Ross G, Felix D, Camilleri IG. The use of sentinel node biopsy in the management of epitheloid haemangioendothelioma of the lip. Oral Oncol. 2003;39:531-3.

8. Wesley RK, Mintz SM, Wertheimer FW. Primary malignant hemangioendothelioma of the gingiva. Report of a case and review of the literature. Oral Surg Oral Med Oral Pathol. 1975;39:103-12.

9. Rosai J, Gold J, Landy R. The histiocytoid hemangiomas. A unifying concept embracing several previously described entities of skin, soft tissue, large vessels, bone, and heart. Hum Pathol. 1979;10:70730 .

10. Mohtasham N, Kharrazi AA, Jamshidi S, Jafarzadeh H. Epithelioid hemangioendothelioma of the oral cavity: a case report. J Oral Sci. 2008;50:219-23.

11. Molina Palma MI, Cervantes Góngora JA, García de la Torre E, Conde Pérez de la Blanca I, Ramírez Tortosa CL. Primary intraoral epithelioid hemangioendothelioma. Case report and review of the literature. Acta Otorrinolaringol Esp. 2002;53:215-8.

12. Machálka M, Procházková L, Husek K. Epithelioid hemangioendothelioma of the mandible. Mund Kiefer Gesichtschir. 2003;7:180-3.

13. Flaitz CM, McDaniel RK, Mackay B, Kennady MC, Luna MA, Hicks MJ. Primary intraoral epithelioid hemangioendothelioma presenting in childhood: review of the literature and case report. U1trastruct Pathol. 1995;19:275-9.

14. Pokharna RK, Garg PK, Gupta SD, Dutta U, Tandon RK. Primary epithelioid haemangioendothelioma of the liver: case report and review of the literature. J Clin Pathol. 1997;50:1029-31.

15. Chi AC, Weathers DR, Folpe AL, Dunlap DT, Rasenberger K, Neville BW. Epithelioid hemangioendothelioma of the oral cavity: report of two cases and review of the literature. Oral Surg Oral Med Oral Pathol Oral Radiol Endod. 2005;100:717-24.

16. Sun ZJ, Zhang L, Zhang WF, Chen XM, Lai FM, Zhao YF. Epithelioid hemangioendothelioma of the oral cavity. Oral Dis. 2007;13:244-50.

17. Ellis GL, Kratochvil FJ 3rd. Epithelioid hemangioendothelioma of the head and neck: a clinicopathologic report of twelve cases. Oral Surg Oral Med Oral Pathol. 1986;61:61-8.

18. Ramer MA, Lumerman H, Kopp W, Fisher KS, Cohen SA. Epithelioid hemangioendothelioma of the maxilla: case report and review of literature. Periodontal Clin Investig. 2001;23:31-5. 